Jurnal Quantum Teknika

Vol. 1, No. 1, Hal 10-13, Oktober 2019

\title{
Pengaruh Tegangan Permukaan Terhadap Tumbukan Multiple Droplets Pada Permukaan Stainles Steel Yang Dipanaskan
}

\author{
Rafil Arizona* \\ Department of Machanical \& Industrial Engineering, Faculty of Engineering, Universitas Gadjah \\ Mada, Jl. Grafika No. 2, Yogyakarta, 55281, Indonesia \\ Penulis korespondensi: afiel165@gmail.com
}

Histori artikel: diserahkan 20 April 2019, direviu 25 Juni 2019, direvisi 15 Juli 2019

\begin{abstract}
The present study was conducted to investigate the dynamics of multiple droplets impact under various surface tensions. Here, the ethylene glycol with compositions of $0 \%, 5 \%$, and $15 \%$ were injected through a nozzle into the stainless steel surface as the multiple droplets. The solid surface was heated at the temperatures of $150^{\circ} \mathrm{C}$. The dynamic of multiple droplets have been observed with frame rate of $2000 \mathrm{fps}$ by a high speed camera. A technique of image processing was developed to determine the maximum droplets are spreading ratio. As the result, the surface tension contribute to the maximum spreading ratio significantly. When the droplet surface tension decreases, the maximum spreading ratio increases. The maximum spreading ratio appears when the percentage of the ethylene glycol is $15 \%$ at the temperature of $150^{\circ} \mathrm{C}$. From the visual observation, it was shown that a slower emergence of secondary droplets (droplet splashing) was carried out under low surface tension.

Keywords: multiple droplets, spreading factor, surface tension, stainless steel.
\end{abstract}

DOI: $10.18196 /$ jqt.010102

Web: http://journal.umy.ac.id/index.php/qt

\section{PENDAHULUAN}

Fenomena tumbukan antara tetesan (droplet) dengan permukaan padat dapat dijumpai pada berbagai aplikasi, salah satunya adalah sebagai proses pendinginan. Proses pendinginan dilakukan dengan sejumlah tetesan air dan dengan penyemprotan atau biasa dikenal sebagai spray cooling. Spray cooling digunakan untuk mendinginkan suatu permukaan panas.

Interaksi droplet dengan permukaan benda padat yang dipanaskan, akan terjadi beberapa fenomena yaitu menyebar (spreading), (rebound) dan menyiprat (splashing) (Chandra dan Avedisian, 1991). Hal ini bisa terjadi karena peningkatan suhu sangat mempengaruhi tegangan permukaan di setiap bahan. Sehingga perilaku droplet di setiap spesimen uji yang berbeda memiliki fenomena yang berbeda - beda. Ethylene glycol adalah zat tidak berwarna, tidak berbau, volatilitas rendah, viskositas rendah, dan cairan higroskopis. Ethylene glycol dapat tercampur dengan air dan cairan organik lainnya.

Bernadin dan Mudawar, (1997) metode spray cooling terbukti dapat membuang heat flux yang tinggi sekaligus mengontrol laju pendinginan yang diinginkan. Laju perpindahan kalor yang tinggi merupakan suatu keuntungan karena dapat mengurangi ukuran, biaya dan kompleksitas peralatan penukar kalor.

Deendarlianto et al., (2014) salah satu sifat dari droplets yang menumbuk permukaan adalah sifat mampu basah (wettability). Kemampuan dari wettability berkaitan erat dengan laju perpindahan kalor yang terjadi antara sebuah tetesan dengan permukaan padat. Semakin luas daerah yang dibasahi oleh tetesan maka semakin besar laju perpindahan kalornya.

Chandra dan Avedisian (1991) meneliti mengenai pengaruh dari suhu pada tumbukan droplet dengan energi tumbukan awal yang 
konstan. Ketika droplet menumbuk permukaan dapat terjadi splash, spread, dan rebound. Diharapkan dari percobaan ini dengan variasi temperatur permukaan yang dilakukan dapat memberikan hasil yang berpengaruh.

Rioboo et al., (2002) menyebutkan the nondimensional diameter dari spreading film atau sering disebut dengan spread factor, akan mengalami perubahan seiring dengan perubahan waktu. Perubahan tersebut dibagi menjadi 4 fase yaitu the kinematic phase, the spreading phase, the relaxation phase, dan a wetting/equilibrium phase.

Li, Ashgriz Nasser dan Chandra Sanjeev (2010) melakukan penelitian mengenai model analisis tentang spreading maksimum pada droplet yang menumbuk benda padat pada bilangan Reynolds dan Weber yang rendah. Penelitian tersebut menyebutkan 4 keadaan yang perlu dipertimbangkan yang akan terjadi pada droplet.

Menurut Vishaul et al., (2011) Ethylene Glycol Jika dibandingkan dengan propylene glycol, bahwa ethylene glycol memiliki spreading maksimum yang lebih rendah karena nilai tegangan permukaannya lebih tinggi. Pengaruh tegangan permukaan pada faktor penyebaran maksimum berkurang dengan meningkatnya kecepatan benturan. Tetesan air menyebar sebanyak tetesan anhidrida asetat meskipun memiliki tegangan permukaan, setengah dari air. The hierarchy according to the number of oscillations continues further with ethylene glycol droplet oscillating for a much longer time than propylene glycol.

Cossali et al., (2005) juga melakukan penelitian menggunakan cairan berbeda, membandingkan air murni dangan campuran air+gliserin. Kondisi eksperimen menunjukkan bahwa analisis efek viskositas terhadap perilaku spreading dan break-up pada secondary droplet. Dengan penambahan gliserin maka viskositas meningkat, Reynolds Number menurun, perpindahan kalor konveksi dari permukaan ke cairan menurun.

Penelitian mengenai dinamika single droplet yang menumbuk permukaan padat sudah banyak dilakukan sebelumnya namun penelitian mengenai fenomena multiple droplet yang menumbuk permukaan padat masih sedikit. Pada penelitian ini akan dipelajari perpindahan kalor dan visualisasi dari fenomena spreading dan recoil multiple droplet ketika menumbuk permukaan datar stainless steel pada temperatur permukaan $150^{\circ} \mathrm{C}$ dengan bilangan Weber sedang. Dari penelitian ini, akan dibandingkan pengaruh dari tegangan permukaan terhadap spreading ratio yang berbeda dari fluida cair ethylene glygol dihasilkan oleh multiple droplet.

\section{METODOLOGI PENELITIAN}

Alat eksperimen yang digunakan dalam penelitian ini ditunjukkan pada Gambar 1 . Pemanasan spesimen digunakan kompor induksi, pemanasan dilakukan pada temperatur $150^{\circ} \mathrm{C}$. Temperatur permukaan diukur menggunakan termokopel. Droplet dijatuhkan ke permukaan yang dipanaskan dengan menggunakan jarum injector. Ukuran droplet dianggap konstan pada $2,8 \mathrm{~mm}$. Frekuensi tetesan diatur dengan control valve. Mengatur frekuensi tetesan pada 250 tetes/menit. Ketinggian jatuh droplet antara jarum injector dan permukaan yang dipanaskan $50 \mathrm{~mm}$ sehingga menghasilkan bilangan Weber sedang.

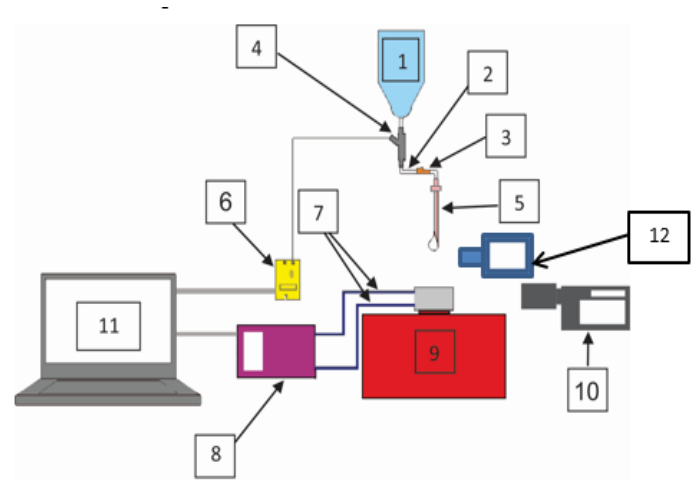

GAMBAR 1. Skema alat uji

Keterangan :

1. Tangki air

2. Selang Silikon

7. Termokopel

3. Control valve

8. Lutron termokopel

4. Solenoid valve

9. Kompor induksi

5. Droplet injector

10. Kamera Phantom

6. Mikrokontroller

11. Komputer

Perilaku tumbukan droplet diamati dengan menggunakan high speed video camera dengan 
kecepatan pengambilan gambar 2000 frame per second (fps). Teknik image processing digunakan untuk mengolah data dari gambar yang berhasil diambil dengan menggunakan high speed camera. Adapun data yang akan diambil adalah spreading factor $(\beta)$. Hal ini dapat dihitung dengan persamaan 1 .

$\beta=\mathrm{d} / \mathrm{d}_{0}$

dimana :

$\beta=$ spreading factor

$\mathrm{d}=$ diameter pembasahan droplet $(\mathrm{m})$

$\mathrm{d}_{0}=$ diameter awal droplet $(\mathrm{m})$

Material yang digunakan pada peneltian ini menggunakan Stainles steel dengan variasi cairan Ethylene glycol.

TABEL 1. Tabel hasil Uji Surface Tension

\begin{tabular}{lccc}
\hline Jenis & $\begin{array}{c}\text { Water + } \\
\mathbf{0 \%} \\
\text { Ethylene } \\
\text { Glycol }\end{array}$ & $\begin{array}{c}\text { Water + } \\
\mathbf{5 \%} \\
\text { Ethylene } \\
\text { Glycol }\end{array}$ & $\begin{array}{c}\text { Water + } \\
\mathbf{1 5 \%} \\
\text { Ethylene } \\
\text { Glycol }\end{array}$ \\
\hline Temeriksaangan & 70,1 & 59,1 & 51,3 \\
Permukaan & $\mathrm{mN} / \mathrm{m}$ & $\mathrm{mN} / \mathrm{m}$ & $\mathrm{mN} / \mathrm{m}$ \\
\hline
\end{tabular}

Variasi Tegangan Permukaan dibuktikan berdasarkan pengamatan visual, pengujian surface tension dengan beberapa variasi ethylene glycol yang ditunjukkan pada Tabel 1.

\section{HASIL DAN PEMBAHASAN}

Pada hasil dan pembahasan akan dilakukan analisis secara visual dan analisis data didapatkan dari hasil pengolahan image processing. Fenomena yang terjadi pada temperatur $150{ }^{\circ} \mathrm{C}$ ditunjukan sebagai berikut: first droplet adalah spreading, recoil dan secondary droplet (Gambar 2). Pada temperatur ini terjadi fenomena baru yaitu perpecahan. Droplet terpecah menjadi satu droplet utama dan beberapa droplet yang lebih kecil. Droplet kecil ini disebut sebagai secondary droplet. Hal tersebut terjadi ketika $\mathrm{T}_{\text {wall }}>\mathrm{T}_{\text {sat liquid maka akan terbentuk bubble }}$ boiling droplet. Pada Bubble yang dihasilkan oleh perpindahan panas dari permukaan spesimen akan berkembang dan menuju permukaan droplet sehingga menghasilkan secondary droplet (Cossali et al., 2005).
Secondary droplet tercepat terjadi pada surface tension $=70,1 \mathrm{mN} / \mathrm{m}$ yaitu pada $\mathrm{t}=183 \mathrm{~ms}$ (Gambar 3). Hal ini disebabkan semakin tinggi surface tension maka mempercepat munculnya secondary droplet karena perpindahan panas dari permukaan specimen menuju permukaan droplet cepat dan semakin kecil surface tension juga memperbesar spreading rationya.

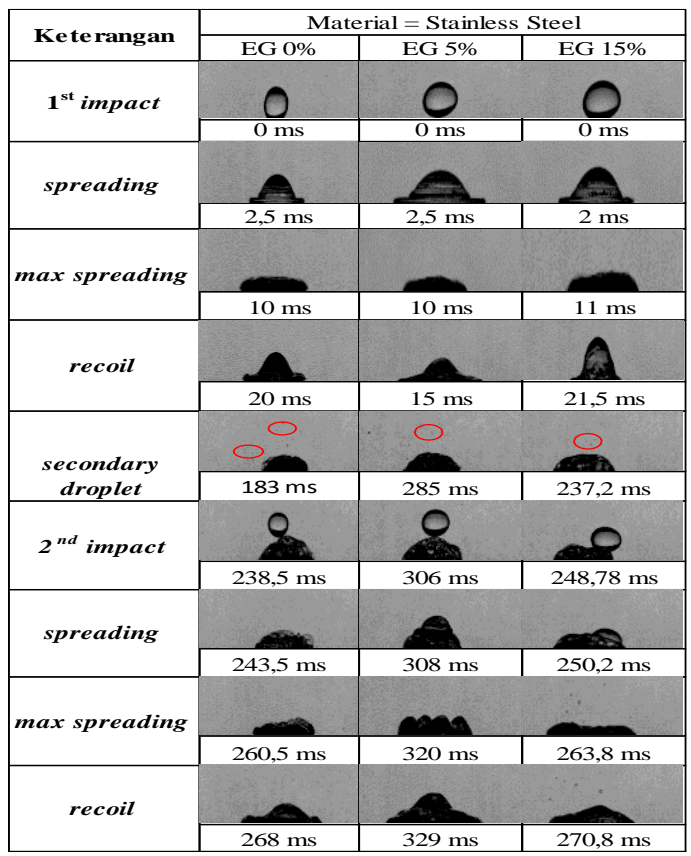

GAMBAR 2. Fenomena spreading, recoil dan secondary droplet pada multiple droplet dengan variasi ethylene glycol pada temperatur $150{ }^{\circ} \mathrm{C}$

Tumbukan antara second droplet dan first droplet pada semua variasi surface tension memiliki pola yang hampir sama. Pada recoil second droplet pada surface tension 59,1 $\mathrm{mN} / \mathrm{m}$ memiliki nilai maksimum spreading 2,96 dapat terlihat pada Gambar 3 .

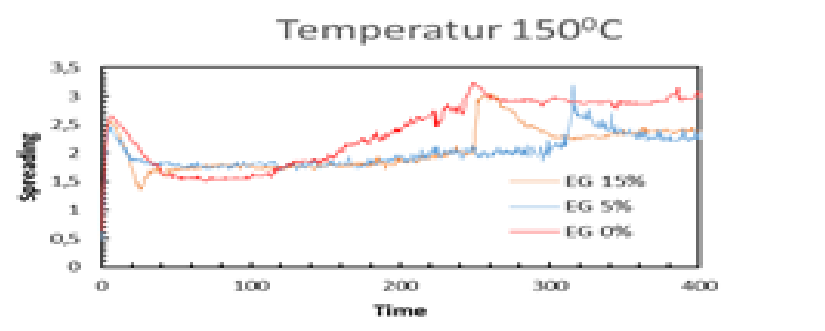

GAMBAR 3. Nilai $d / d_{0}$ sebagai fungsi waktu dengan variasi ethylene glycol pada temperatur $150^{\circ} \mathrm{C}$.

KESIMPULAN 
Pada temperatur $150{ }^{\circ} \mathrm{C}$ semakin kecil surface tension juga memperbesar spreading ratio dan semakin tinggi surface tension maka mempercepat munculnya secondary droplet.

Berdasarkan eksperimen yang telah dilakukan pada keseluruhan temperatur permukaan memiliki fenomena pengaruh surface tension terhadap spreading ratio yang sama, yaitu semakin kecil surface tension maka akan semakin besar spreading ratio.

\section{DAFTAR PUSTAKA}

Bernadin, J.D.dan Mudawar,I. (1997). Film Boiling Heat Transfer of Droplet Stream and sprays. International Journal of Heat and Mass Transfer, 40(11), (pp.579-593).

Bernardin, JD, Stebbins, CJ, Mudawar, I (1997), Mapping of impact and heat transfer regimes of water drops impinging on a polished surface, International Journal of Heat Mass Transfer, vol. 40, (pp. 247 - 267).

Chandra, S. dan Avedisian, C.T., (1991). On The Collision Of A Droplet With A Solid Surface. Proceedings of The Royal Society A: Mathematical, Physical and Engineering Sciences, 431(1884), (pp. 13-41).

Cossali, G.E, Marengo, M, Santini, M, (2005), Secondary atomisation produced by single drop vertical impacts onto heated surfaces, Experimental Thermal and Fluid Science 29 (pp. 937-946).

Deendarlianto, Yasuki, T., Sumitorno, H., Indarto,Widyaparaga, A., Kamal, S., Purnomo, dan Kohno, M. (2014). Effect of Static Contact Angle on The Droplet Dynamics During The Evaporation of a Water Droplet on The Hot Walls. International Journal of Heat and Mass Transfer, 71, (pp.691-705).

Li, R., Ashgriz, N., \& Chandra, S. (2010). Maximum spread of droplet on solid surface: low Reynolds and Weber numbers. Journal of Fluids Engineering, 132(6), 061302.

Rioboo, R., Marengo, M., dan Tropea, C. (2002). Outcomes from A Drop Impact on Solid Surfaces. Journal of Fluids Engineering, 132(6), (pp.112-124).
Vishaul Ravi, (2011). Effects on Interfacial and Viscous Properties of Pure Liquids and Polymeric Solutions on Drop Spread Dynamics, Thesis, Department of Mechanical, Industrial and Nuclear Engineering, Anna University, India.

Wibowo, T, Widyatana, A, Kamal, S, Indarto, Deendarlianto (2018), The effect of pressure and frequency on the dynamic behavior and evaporation time of successive water droplets impacting onto hot surface, MATEC Web of Conferences 154, 2018.

Yarin, A. L. (2006a) and (2006b). Drop impact dynamics: Splashing, spreading, receding, bouncing. Annual Review of Fluid Mechanics, 38(1), 159-192. 